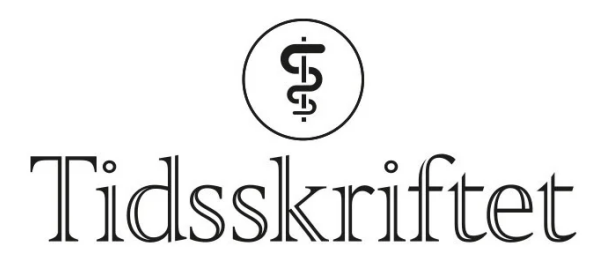

DEN NORSKE LEGEFORENING

\title{
Dødsfall etter påvist SARS-CoV-2 i Norge
}

ORIGINALARTIKKEL

\section{HANNE LøVDAL GULSETH}

hannelovdal.gulseth@fhi.no

Avdeling for kroniske sykdommer og aldring

Folkehelseinstituttet

Hun har bidratt med idé, design, tolking av resultater og utarbeiding og revisjon av manuset og har godkjent innsendte manusversjon.

Hanne Løvdal Gulseth er ph.d., lege og avdelingsdirektør.

Forfatteren har fylt ut ICMJE-skjemaet og oppgir ingen interessekonflikter.

\section{EYVIND HELLAND}

Avdeling helseregistre

Helsedirektoratet

Han har bidratt med analyser, tolking av resultater og utarbeiding og revisjon av manuset og har godkjent innsendte manusversjon.

Eyvind Helland er ph.d.-student i psykologi ved NTNU og rådgiver.

Forfatteren har fylt ut ICMJE-skjemaet og oppgir ingen interessekonflikter.

\section{KNUT IVAR JOHANSEN}

Avdeling helseregistre

Helsedirektoratet

Han har bidratt med tolking av resultater og utarbeiding og revisjon av manuset og har godkjent innsendte manusversjon.

Knut Ivar Johansen er sosiolog og seksjonssjef.

Forfatteren har fylt ut ICMJE-skjemaet og oppgir ingen interessekonflikter.

\section{KIRSTEN GRAVNINGEN}

Avdeling for smittevern og beredskap

Folkehelseinstituttet

Hun har bidratt med tolking av resultater og utarbeiding/revisjon av manuset og har godkjent innsendte manusversjon.

Kirsten Gravningen er ph.d., spesialist i medisinsk mikrobiologi og overlege.

Forfatteren har fylt ut ICMJE-skjemaet og oppgir ingen interessekonflikter.

\section{HELENA NIEMI EIDE}

Avdeling for smittevern og beredskap

Folkehelseinstituttet

Hun har bidratt med tolking av resultater og utarbeiding og revisjon av manuset og har godkjent innsendte manusversjon.

Helena Niemi Eide er lege og master i folkehelse. 


\section{SIRI ELDEVIK HÅBERG}

Senter for fertilitet og helse

Folkehelseinstituttet

Hun har bidratt med idé, design, tolking av resultater og utarbeiding og revisjon av manuset og har godkjent innsendte manusversjon.

Siri Eldevik Håberg er ph.d., lege og fagdirektør.

Forfatteren har fylt ut ICMJE-skjemaet og oppgir ingen interessekonflikter.

\section{INGER JOHANNE BAKKEN}

Avdeling helseregistre

Helsedirektoratet

Hun har bidratt med idé, design, dataanalyse, tolking av resultater og utarbeiding og revisjon av selve manuset og har godkjent innsendte manusversjon.

Inger Johanne Bakken er dr.ing. og seniorrådgiver.

Forfatteren har fylt ut ICMJE-skjemaet og oppgir ingen interessekonflikter.

\section{BAKGRUNN}

Høy alder er den viktigste risikofaktoren for død som følge av covid-19, men kunnskapen om betydningen av kroniske sykdommer er mangelfull. Gjennom bruk av helseregisterdata beskriver vi sykdomsprofiler for personer som døde etter å ha fått påvist SARS-CoV-2 i pandemiens tre første måneder i Norge.

\section{MATERIALE OG METODE}

Data fra spesialisthelsetjenesten (Norsk pasientregister, NPR) og primærhelsetjenesten (Kommunalt pasient- og brukerregister, KPR) er koblet med informasjon om positive SARSCoV-2-prøver fra Meldingssystem for smittsomme sykdommer (MSIS) og dødsfall fra Folkeregisteret. Uttrekket omfatter befolkningen i Norge per 1.3.2020, med data for påvist smitte, sykehusinnleggelser og død til 31.5.2020.

\section{RESULTATER}

Av 8412 personer med påvist SARS-CoV-2 døde 244 (2,9\%), hvorav 133 (55\%) var menn. Andelen med påvist smitte som døde, varierte fra o,2 \% (alder <6o år) til 52 \% (alder $\geq 90$ år). I alt 92 (38\%) døde på sykehus. $25(16 \%)$ av de som døde utenfor sykehus, hadde tidligere sykehusinnleggelse for covid-19. Andelen uten registrert kronisk sykdom var $39 \% \mathrm{i}$ aldersgruppen $<70$ år og 26 \% i aldersgruppen $\geq 70$ år. Sykdomsfordelingen varierte ved dødsfall i og utenfor sykehus, særlig for diabetes, nyresvikt og demensdiagnoser.

FORTOLKNING

Andelen som døde blant personer med påvist SARS-CoV-2 i pandemiens tre første måneder i Norge, var lav. Flertallet av de døde var 70 år eller eldre og hadde minst én kronisk sykdom, men sykdomsprofilen varierte i og utenfor sykehus. Helseregisterdata kan bidra til bedre oversikt over og rådgiving til risikogrupper i befolkningen under en pågående pandemi.

\section{HOVEDFUNN}

Per 31.5.2020 var det registrert 244 dødsfall blant personer med påvist SARS-CoV-2 i Norge, dvs. $2,9 \%$ av alle med positiv prøve.

Av 145 personer som var 90 år eller eldre og hadde påvist smitte, døde over halvparten.

Kobling av flere helseregistre viste at blant de som døde, var tre av fire registrert med én eller flere kroniske sykdommer. 
Det var store forskjeller i alders- og sykdomsprofiler mellom de som døde på og utenfor sykehus.

Det første dødsfallet i Norge som skyldtes covid-19, sykdommen forårsaket av viruset SARS$\mathrm{CoV}-2$, ble rapportert 12.3.2020. Per 10.6.2020 opplyste Folkehelseinstituttet at det var registrert 239 dødsfall i Norge knyttet til covid-19 i Meldesystem for smittsomme sykdommer (MSIS) (1, 2), og samme dag rapporterte Verdens helseorganisasjon over 370 ooo dødsfall globalt som kunne tilskrives covid-19-pandemien (11). Flere europeiske land har rapportert høyere dødelighet enn forventet (overdødelighet) under pandemien (ㅁ) , mens generell dødelighet i befolkningen i Norge frem til juni var normal, også blant personer over 70 år (3).

Tall fra Norge og andre land viser at høy alder er den viktigste risikofaktoren for alvorlig sykdomsforløp og død hos pasienter med covid-19, og at underliggende sykdommer ser ut til å øke risikoen ytterligere (4-7.). Studier fra andre land har vist at ikke-smittsomme sykdommer som diabetes, hjerte- og karsykdommer, kreft og kroniske lunge- og nyresykdommer sammen med alder, kjønn (mann) og fedme kan være risikofaktorer for død som følge av covid-19 (므).

Å identifisere grupper i befolkningen med økt risiko for alvorlig sykdomsforløp og død ved infeksjon med et nytt virus med stor spredningsevne er nødvendig for å kunne gi kunnskapsbaserte råd om målrettede tiltak. Folkehelseinstituttet har utarbeidet råd om forebyggende tiltak til grupper med underliggende tilstander basert på foreliggende evidens fra andre land $(\underline{6}, \underline{8})$, og rådene oppdateres jevnlig.

Oversikt over befolkningens helse, sykdomsforekomst, dødelighet og helsetjenestebruk er grunnleggende for god håndtering av sykdomsutbrudd og epidemier. Data fra nasjonale helseregistre bidrar til bedre planlegging av helsetjenesten og kan også brukes til å analysere mulige konsekvenser og effekt av tiltak (9.).

I denne artikkelen beskriver vi dødsfall blant pasienter med påvist SARS-CoV-2 i Norge gjennom kobling av nasjonale registerdata. Vi har unders $\emptyset$ kt forekomst av kroniske sykdommer og underliggende tilstander i denne populasjonen.

\section{Materiale og metode}

I forbindelse med utbruddet av covid-19 har Helsedirektoratet og Folkehelseinstituttet etablert et samarbeidsprosjekt der hensikten er å bruke helseregisterdata for raskt å skaffe oversikt over covid-19-situasjonen i Norge. Det legges spesiell vekt på sykdomsutvikling og død i risikogrupper (므, $\underline{11})$.

Helsedirektoratets avdeling helseregistre har tilrettelagt statistikken basert på data fra MSIS (므), Norsk pasientregister (NPR) og Kommunalt pasient- og brukerregister (KPR) (9). Datahåndteringen er hjemlet i forskriftene for registrene. Medarbeiderne i Helsedirektoratet hadde ikke tilgang til fødselsnumre eller andre direkte personidentifiserbare kjennetegn. Medarbeiderne i Folkehelseinstituttet har kun tilgang til aggregerte data som ikke kan tilbakeføres til enkeltpersoner.

Utvalget omfatter 8412 personer med SARS-CoV-2 påvist med PCR-test meldt til MSIS til og med 31.5.2020. Datasettet ble avgrenset til å omfatte alle personer som var registrert med dato for død i Personregisteret (PREG, Norsk helsenetts kopi av Folkeregisteret) (13), i alt 244 personer per 10.6.2020. Siste dato for død i denne oppdateringen var 29.5.2020.

For disse 244 personene ble det innhentet informasjon fra registre over helsetjenestebruk som forvaltes av Helsedirektoratet: NPR for spesialisthelsetjenesten og KPR for primærhelsetjenesten. Sykdommer og tilstander som kunne gi økt risiko for alvorlig forløp 
av covid-19, ble definert med bakgrunn i kunnskap om covid-19-forløp fra andre land, smitterisiko for influensa og sykdommers forløp samt behandling og mulige effekter på immunsystemet (ㅁ) . Vi inkluderte en lang rekke sykdommer, fordi beredskap og overvåking var hovedformålet med prosjektet og kunnskapen om covid-19 var begrenset (11). Definisjon av risikotilstander er basert på registrerte koder, ICD-1o (internasjonal statistisk klassifikasjon av sykdommer og beslektede helseproblemer) i NPR og ICPC-2 (internasjonal klassifikasjon for primærhelsetjenesten) i KPR. Primært har vi sett på ikkesmittsomme sykdommer som diabetes, hjerte- og karsykdom, kreft og kronisk lungesykdom, som definert i tabell 1. Vi gjorde også en bredere analyse der vi inkluderte fedme og gastrointestinale, revmatiske og nevrologiske sykdommer; se (1ㅡ) for ytterligere definisjon. For noen kroniske sykdommer benyttet vi alle tilgjengelige data tilbake i tid, mens vi for andre gikk syv eller fem år tilbake i tid avhengig av kunnskap om sykdomsforl $\varnothing \mathrm{p}(\underline{11})$. Vi hadde ikke tilgang til data om legemiddelbruk generelt, men Helsedirektoratet har oversikt over helseforetaksfinansierte legemidler brukt i og utenfor sykehus (h-reseptlegemidler). Dette omfatter for eksempel biologiske legemidler som infliksimab og adalimumab samt en del kreftlegemidler.

\section{Tabell 1}

Definisjoner for aktuelle kroniske sykdommer og tilstander undersøkt for personer døde etter påvist SARS-CoV-2.

\begin{tabular}{|llll|}
\hline Sykdom/tilstand & Periode & Datakilde & \\
\hline & & $\begin{array}{l}\text { Norsk } \\
\text { pasientregister } \\
\text { (ICD-10-koder) }\end{array}$ & $\begin{array}{l}\text { Kommunalt } \\
\text { pasient- og } \\
\text { brukerregister } \\
\text { (ICPC-2-koder) }\end{array}$ \\
\hline Diabetes & Alle tilgjengelige data ${ }^{1}$ & E10, E11 & T89, T90 \\
\hline $\begin{array}{l}\text { Hjerte- og } \\
\text { karsykdommer }\end{array}$ & Siste fem år & G45, H34, 100-99 & $\begin{array}{l}\text { K74-80, K82, K83, } \\
\text { K85-87, K89-92 }\end{array}$ \\
\hline Kreft & Siste fem år & C00-97, D32-33, & \\
& & D35.2-35.4, D42, & \\
D43, D44.3-44.5, & \\
D45-47 & \\
\hline $\begin{array}{l}\text { Kronisk } \\
\text { lungesykdom }\end{array}$ & Siste fem år & J41-47, J84, J98 & R95, R96 \\
\hline $\begin{array}{l}\text { Demens } \\
\text { Alle tilgjengelige data }{ }^{1}\end{array}$ & $\begin{array}{l}\text { F00-03, G30, } \\
\text { G31.0, G31.2, G31.8, }\end{array}$ \\
\hline $\begin{array}{l}\text { Nyresvikt } \\
\text { Alle tilgjengelige data }{ }^{1}\end{array}$ & N18.3-18.5 & \\
\hline $\begin{array}{l}\text { Leversvikt } \\
\text { Tilstander som } \\
\text { påvirker } \\
\text { immunfunksjon } \\
\text { (transplantasjon, } \\
\text { immunsvikt) }\end{array}$ & Alle tilgjengelige data ${ }^{1}$ & K70.4, K72 & \\
\hline
\end{tabular}

${ }^{12008-19}$ i Norsk pasientregister og juli 2016-mars 2020 i Kommunalt pasient- og brukerregister. 
Microsoft SQL Server ble brukt for uthenting av data fra databasene og de første tilretteleggingene av variablene. Kobling av data og tilrettelegging av tabeller ble gjennomført i analyseverktøyet $\mathrm{R}$ (www.rstudio.com). Vi presenterer deskriptiv statistikk fordelt på kjønn, alder og dødsfall i og utenfor sykehus. Av personvernhensyn inngår ikke informasjon om bosted eller detaljer om fordeling på kjønn og alder. Vi har gruppert alle risikogruppene sammen og viser statistikk for antall og andel uten registrert kronisk sykdom eller tilstand. I tillegg viser vi hvor mange som er registrert med minst én av sykdommene eller tilstandene definert i tabell 1 og minst én eller to av de ikke-smittsomme sykdommene (diabetes, hjerte- og karsykdom, kreft og kronisk lungesykdom).

\section{Resultater}

Av 8412 personer i Norge med påvist SARS-CoV-2 var 244 (2,9\%) registrert døde i Folkeregisteret per 31.5.2020 i en oppdatering gjort 10.6.2020. Median alder ved død var 85 år (interkvartilområde 77-90 år), og 133 ( $55 \%$ ) var menn. Det var flest dødsfall i aldersgruppen 8o-89 år og færrest blant dem under 6o år. Letaliteten, definert som andelen døde av antallet med påvist smitte, var høyest i de eldste aldersgruppene og varierte fra $0,2 \%$ hos dem under 60 år til $52 \%$ hos dem over 90 år (tabell 2). Median antall dager mellom påvist SARS-CoV-2 og død var 10 (interkvartilområde 6-16 dager). I fire tilfeller var prøvedato lik eller senere enn dødsdato.

\section{Tabell 2}

Antall dødsfall registrert blant personer med påvist SARS-CoV-2 i Norge per 31.5.2020. Letalitet er andel dødsfall av antall positive prøver.

\begin{tabular}{|lcccr|}
\hline & $\begin{array}{l}\text { Antall dødsfall } \\
\text { (\%av total) }\end{array}$ & $\begin{array}{l}\text { Antall } \\
\text { menn (\%) }\end{array}$ & $\begin{array}{l}\text { Antall dødsfall } \\
\text { på sykehus (\%) }\end{array}$ & $\begin{array}{l}\text { Antall med } \\
\text { påvist smitte } \\
\text { (letalitet, \%) }\end{array}$ \\
\hline Alle & 244 & $133(55)$ & $92(38)$ & $8412(2,9)$ \\
\hline Aldersgrupper (år) & & & & \\
\hline $0-69$ & $31(13)$ & $26(84)$ & $26(84)$ & $7287(0,4)$ \\
\hline $70-79$ & $46(19)$ & $29(63)$ & $22(48)$ & $602(8)$ \\
\hline $80-89$ & $91(37)$ & $49(54)$ & $28(31)$ & $378(24)$ \\
\hline$\geq 90$ & $76(31)$ & $29(38)$ & $16(21)$ & $145(52)$ \\
\hline
\end{tabular}

${ }^{1}$ Tallene er små i aldersgruppen under 70 år, og alle detaljer kan derfor ikke oppgis av personvernhensyn. Det var 11 dødsfall (4,5\%) i aldersgruppen under 60 år, letalitet 0,2 \%, og 20 dødsfall (8,2 \%) i alderen 6o-69 år, letalitet 2,1\%.

Til sammen 92 personer ( $38 \%$ ) var registrert døde på sykehus. I aldersgruppen under 70 år skjedde 26 av 31 ( $84 \%$ ) dødsfall på sykehus, mens tilsvarende andel var $21 \%(16$ av 76$) \mathrm{i}$ gruppen 90 år og eldre. Av de 152 som døde utenfor sykehus, var det 25 (16\%) som var registrert med tidligere sykehusopphold kodet med covid-19, og 15 av disse døde i løpet av de syv første dagene etter utskrivelse.

I alt 67 personer ( $27 \%$ ) av dem som døde, var ikke tidligere registrert med kronisk somatisk sykdom eller tilstand (tabell 3 ). Andelen uten registrering for kronisk sykdom var tilnærmet lik i og utenfor sykehus, $28 \%$ vs. $27 \%$. De vanligste registrerte tilstandene var hjerte- og karsykdom (55\%), diabetes (21\%), kreft (16,8\%) og lungesykdom (16,4\%). Blant 
personer under 70 år var andelen uten registrert kronisk sykdom større (39\%) enn hos personer over 70 år (26\%), men andelen med diabetes og nyresvikt var større hos dem under 70 år.

\section{Tabell 3}

Kroniske sykdommer og risikotilstander blant personer døde etter påvist SARS-CoV-2 i Norge per 31.5.2020. Undergrupper med små tall som av personvernhensyn ikke kan oppgis eksakt, er angitt med -.

\begin{tabular}{|c|c|c|c|c|c|}
\hline & $\begin{array}{l}\text { Antall blant } \\
\text { alle døde } \\
(\%), \mathrm{n}=244\end{array}$ & $\begin{array}{l}\text { Antall blant } \\
\text { døde utenfor } \\
\text { sykehus (\%), } \\
n=152\end{array}$ & $\begin{array}{l}\text { Antall blant } \\
\text { døde på } \\
\text { sykehus (\%), } \\
n=92\end{array}$ & $\begin{array}{l}\text { Antall } \\
\text { blant } \\
\text { døde }< \\
70 \text { år }(\%), \\
n=31\end{array}$ & $\begin{array}{l}\text { Antall blant } \\
\text { døde } \geq 70 \text { år } \\
(\%), n=213\end{array}$ \\
\hline $\begin{array}{l}\text { Ingen registrert } \\
\text { kronisk sykdom med } \\
\text { antatt forhøyet risiko }\end{array}$ & $67(28)$ & $41(27)$ & $26(28)$ & $12(39)$ & $55(26)$ \\
\hline $\begin{array}{l}\text { Minst én ikke- } \\
\text { smittsom sykdom² }\end{array}$ & $169(69)$ & $104(68)$ & $65(71)$ & $18(58)$ & $151(71)$ \\
\hline $\begin{array}{l}\text { Minst to ikke- } \\
\text { smittsomme } \\
\text { sykdommer }^{2}\end{array}$ & $77(32)$ & $43(28)$ & $34(37)$ & $7(23)$ & $70(33)$ \\
\hline Hjerte- og karsykdom & $134(54)$ & $88(58)$ & $46(50)$ & $12(39)$ & $122(57)$ \\
\hline Diabetes & $50(21)$ & $22(14)$ & $28(30)$ & $8(26)$ & $42(20)$ \\
\hline Kreft & $41(17)$ & $25(16)$ & $16(17)$ & & $-3^{3}$ \\
\hline Kronisk lungesykdom & $40(16)$ & $24(16)$ & $16(17)$ & & -4 \\
\hline Demens & $36(15)$ & $36(24)$ & 0 & & -5 \\
\hline Nyresvikt & $16(7)$ & -6 & & $5(16)$ & $11(5)$ \\
\hline $\begin{array}{l}\text { Tilstander som } \\
\text { påvirker } \\
\text { immunfunksjon } \\
\text { (transplantasjon, } \\
\text { immunsvikt) }\end{array}$ & $5(2)$ & 0 & $5(5)$ & & -7 \\
\hline
\end{tabular}

${ }^{1}$ Kroniske sykdommer som definert i tabell 1 , tallene er for små til å kunne oppgis for leversvikt separat.

${ }^{2}$ Samlebetegnelse for diabetes, hjerte- og karsykdom, kreft og kronisk lungesykdom.

${ }^{3}$ De aller fleste registrert med kreftsykdom var i den eldste aldersgruppen.

${ }^{4}$ Forskjellen i andel med lungesykdommer mellom aldersgruppene var relativt liten.

${ }^{5}$ De aller fleste tidligere registrert med demens var i den eldste aldersgruppen.

${ }^{6}$ De aller fleste tidligere registrert med nyresvikt døde utenfor sykehus.

${ }^{7} \mathrm{Av}$ de som døde med tidligere registrerte tilstander relatert til immunfunksjon, var det flest i den yngste aldersgruppen. 
Sykdomsprofilene hos dem som døde på sykehus, var forskjellige fra profilene hos dem som døde utenfor sykehus. De som døde på sykehus, hadde oftere minst to registrerte ikkesmittsomme sykdommer. Andelen med diabetes var 30,4\% blant dem som døde på sykehus, og 14,5\% blant dem som døde utenfor sykehus. De aller fleste med diabetes hadde type 2-diabetes. Det var ingen tilfeller av død hos personer med registrert type 1-diabetes $\mathrm{i}$ alderen under 80 år. Alle personene med registrert demensdiagnose døde utenfor sykehus. Det var fem dødsfall hos personer registrert med sykdom eller tilstand som påvirker immunforsvaret. Alle disse dødsfallene skjedde på sykehus, og de fleste av disse personene hadde gjennomgått en transplantasjon. Ingen av de døde hadde fått utlevert et hreseptlegemiddel i 2019, og det var ingen dødsfall blant personer i aktiv kreftbehandling. Når vi brukte et bredere søk for definisjon av kronisk sykdom, som også inkluderte fedme og gastrointestinale, revmatiske og nevrologiske sykdommer, fant vi ytterligere elleve personer. Altså var det bare totalt $23 \%$ (56 av 244) som ikke hadde en kronisk somatisk tilstand.

\section{Diskusjon}

I vårt datasett, som omfatter dødsfall frem til 1.6.2020, var median alder ved død etter påvist SARS-CoV-2-smitte 85 år. Andelen døde (letaliteten) i Norge var lav (2,9\%), men $\emptyset$ kte betydelig med alder. I våre tall var letaliteten for personer over 90 år på 52 \%. Høy letalitet blant de eldste pasientene er vist i en rekke land og viser hvor viktig det er å beskytte de mest sårbare i befolkningen (14). Ikke alle får symptomer ved infeksjon med SARS-CoV-2, og andre får så milde symptomer at de ikke testes. Testkriteriene og testkapasiteten kan også variere over tid og mellom regioner og land. Avgjørende for letaliteten er hvor mange som testes og får påvist sykdommen (14). For land som har testet svært mange med mild eller ingen sykdom, vil dette bidra til at letaliteten blir lavere. Per 7.6.2020 rapporterte Island, som har gjennomført utstrakt testing, en letalitet på o,6 \%, Finland 4,6 \%, Danmark 4,9\% og Sverige, som har vært hardt rammet av pandemien, 10,4\% (15, 16).

Vi fant at to av tre dødsfall etter påvist SARS-CoV-2 skjedde utenfor sykehus. Tall fra MSIS viser at de fleste av disse dødsfallene skjedde på annen helseinstitusjon, mest sannsynlig på sykehjem (트), og kun et fåtall døde utenfor institusjon. Siden positive SARS-CoV-2-prøver ble hentet ut av MSIS og koblet opp mot dødsfall i Folkeregisteret, ble prøvetakingssted i MSIS antatt å være identisk med stedet der pasienten døde. Dette vil i de aller fleste tilfeller være korrekt, men vi kan ikke utelukke at feilklassifisering kan ha skjedd. MSIS får innrapportert om pasienten ved prøvetaking var hjemme eller innlagt i sykehus, sykehjem eller annen helseinstitusjon, men ikke hvilken type annen helseinstitusjon, og ikke hvorvidt personer har hatt langtidsopphold på sykehjem, innlegges på korttidsopphold fra hjemmet eller overføres fra sykehus til midlertidig opphold på sykehjem. I vår studie var det 15 personer som døde i løpet av den første uken etter utskrivelse fra et sykehusopphold med covid-19-diagnose, men vi kjenner ikke detaljene i sykehistoriene eller funksjonsstatus for disse personene. Helsedirektoratet anbefaler at sykehjemsbeboere som blir syke med covid-19, behandles på sykehjemmet og ikke innlegges på sykehus, med mindre det er særlig tungtveiende grunner for at innleggelse vil forlenge livet vesentlig og gi økt livskvalitet (17.). Sykehjemspopulasjonen er spesielt sårbar for alvorlig forløp og død ved covid-19 på grunn av høy alder, underliggende kronisk sykdom og skrøpelighet, og i tillegg er det vist at det er høy risiko for rask spredning blant beboere på sykehjem $(\underline{18}, 19$.$) . Eldre$ og skrøpelige pasienter har ofte atypiske symptomer, noe som øker risikoen for at sykdommen oversees eller oppdages sent. For å forebygge utbrudd på sykehjem er det derfor særlig viktig med høy kvalitet på smittevern, god overvåking av symptomer, lav terskel for SARS-CoV-2-testing og isolering av smittede.

Ved dødsfall utenfor sykehus var hjerte- og karsykdom og demens de vanligste underliggende sykdommene. Vi har tidligere unders $\emptyset \mathrm{kt}$ forekomst av underliggende sykdommer hos personer innlagt med covid-19 (11). I den studien var andelen 
sykehusinnlagte med demensdiagnose lik andelen med demensdiagnose i den generelle befolkningen. Det er derfor interessant at demensdiagnoser ikke ble identifisert hos noen av pasientene som døde på sykehus. Dette kan tyde på etterlevelse av Helsedirektoratets anbefaling om at sykehjemsbeboere med alvorlig covid-19 bør behandles utenfor sykehus (17.). I en studie av covid-19-utbrudd på sykehjem i Bergen ble svært få beboere innlagt på sykehus. Forfatterne diskuterte om årsaken kunne være at sykehjemmene hadde gjort et grundig arbeid med å avklare behandlingsnivået for den enkelte beboer i forkant av covid19-epidemien (19). I tråd med danske (5) og italienske studier (20) fant vi en større andel med diabetes blant dem som døde på sykehus enn blant dem søm døde utenfor sykehus. I de første ukene av pandemien var man særlig bekymret for personer med tilstander eller behandling som påvirker immunforsvaret. I vår studie var det bare fem personer med en slik tilstand som var registrert døde etter påvist SARS-CoV-2, og det var ingen dødsfall blant personer i aktiv kreftbehandling ellers blant personer som brukte biologiske legemidler forskrevet på h-resept.

Styrken ved denne studien er at den omfatter alle personer bosatt i Norge og alle dødsfall hos personer med påvist SARS-CoV-2. Registerkoblingene gjør at vi får data for prospektivt registrerte somatiske diagnoser fra både spesialist- og primærhelsetjenesten. Selv om kvaliteten på noen diagnoser i helseregistrene varierer, er fordelen at disse diagnosene er registrert fortløpende slik at man unngår de skjevheter som kan oppstå når risikotilstandene rapporteres av avdødes lege.

En svakhet ved studien er at vi ikke kan vite om covid-19 var direkte årsak til dødsfallet. Teoretisk kunne pasienten blitt frisk fra infeksjonen og deretter dødd av annen årsak. Vi anser det imidlertid av flere grunner sannsynlig at de aller fleste personer som inngår i statistikkgrunnlaget, faktisk har dødd av SARS-CoV-2, fordi det var kort tid mellom påvist smitte og død, alle med påvist smitte som døde på sykehus, hadde covid-19 som hoved- eller bidiagnose, og covid-19-dødsfall meldt til MSIS var numerisk nokså likt vårt utvalg, henholdsvis 239 og 244 personer. En gjennomgang av journaler slik at covid-19 som dødsårsak kunne verifiseres, ville ha styrket studiens validitet.

I september 2020 offentliggjorde Folkehelseinstituttet preliminære data fra Dødsårsaksregisteret om covid-19 som dødsårsak og sammenhengen med kroniske sykdommer (21). Disse analysene omfatter perioden mars-mai 2020, og Dødsårsaksregisteret rapporterer at covid-19 var registrert som underliggende dødsårsak i 215 ( $91 \%$ ) av de 236 laboratoriebekreftede tilfellene meldt til Dødsårsaksregisteret. Det var registrert kroniske sykdommer på dødsmeldingen i 89\% av covid-19-assosierte dødsfall, og ved å registrere kronisk sykdom på denne måten har Dødsårsaksregisteret brukt en bredere definisjon av kronisk sykdom enn vi har gjort i vår analyse. Sykdomsprofilen er noe forskjellig fra det vi fant, med mindre rapportert diabetes og mer demens i data fra Dødsårsaksregisteret. Dette understreker behovet for å bruke flere kilder samtidig når man studerer slike komplekse problemstillinger.

Aggregerte data basert på registerkoblinger kan være en god kilde til informasjon om risikogrupper under en pandemi, men er ikke tilstrekkelig for avanserte analyser. Det etableres nå derfor et større forskningsprosjekt der individdata om underliggende sykdom og risikotilstander også kobles mot dødsårsaker fra Dødsårsaksregisteret, legemiddelbruk fra Reseptregisteret og data om sosioøkonomiske forhold og landbakgrunn fra Statistisk sentralbyrå.

\section{KONKLUSJON}

Andelen som døde etter påvist SARS-CoV-2 i pandemiens først tre måneder i Norge, var lav $(2,9 \%)$, men letaliteten var over $50 \%$ i aldersgruppen over 90 år. De fleste av dem som døde, hadde registrert minst én kronisk sykdom, men i aldersgruppen under 70 år var det ved fire av ti dødsfall ikke registrert noen tidligere kronisk sykdom eller tilstand. Ingen med registrert demensdiagnose døde på sykehus. Personer som døde på sykehus, var yngre og 
oftere registrert med diabetes eller tilstander som påvirker immunsystemet, og hadde oftere flere tilstander samtidig. Norske helseregistre er gode kilder for å få oversikt over risikotilstander og forløp under en pågående pandemi.

Artikkelen er fagfellevurdert.

\section{LITTERATUR}

1. Coronavirus disease (COVID-19) Situation Report - 133 Data as received by WHO from national authorities by 10:00 CEST, 01 June 2020. https://www.who.int/docs/defaultsource/coronaviruse/situation-reports/20200601-covid-19-sitrep-133.pdf?sfvrsn=9a56f2ac_4 Lest 9.11.2020.

2. EUROMOMO. Graphs and maps, week 2020-25. https://www.euromomo.eu/graphs-and-maps Lest 9.11.2020.

3. Folkehelseinstituttet. COVID-19 Ukerapport - uke 26.

https://www.fhi.no/contentassets/8a971e7boa3c4ao6bdbf381ab52e6157/vedlegg/andre-halvar2020/2020.07.01-ukerapport-uke-26-covid-19-pdf.pdf Lest 9.11.2020.

4. Williamson EJ, Walker AJ, Bhaskaran Ket al. Factors associated with COVID-19-related death using OpenSAFELY. Nature 2020; 584: 430-6. [PubMed][CrossRef]

5. Reilev M, Kristensen KB, Pottegaard A et al. Characteristics and predictors of hospitalization and death in the first 9,519 cases with a positive RT-PCR test for SARS-CoV-2 in Denmark: A nationwaide cohort. International Journal of Epidemiology 2020; dyaa14o. [CrossRef]

6. Flodgren GM, Vestheim DF, Brurberg KG. Covid-19 og risikofaktorer for alvorlig sykdom - en hurtigoversikt, andre oppdatering. Oslo: Folkehelseinstiuttet, 2020.

https://www.fhi.no/publ/2020/Covid-19-og-risikofaktorer-for-alvorlig-sykdom-en-hurtigoversiktandre-oppdatering/ Lest 9.11.2020.

7. Covid-19-epidemien. Kunnskap, situasjon, prognose, risiko og respons i Norge etter uke 26. Notat. Oslo: Folkehelseinstituttet, 2020.

https://www.fhi.no/contentassets/c9e459cd7cc24991810aod28d78o3bdo/vedlegg/covid-19-epidemien--kunnskap-situasjon-prognose-risiko-og-respons-i-norge-etter-uke-26-01.07.2020.pdf Lest 9.11.2020.

8. Folkehelseinstituttet. Råd og informasjon til risikogrupper og pårørende. https://www.fhi.no/nettpub/coronavirus/fakta/risikogrupper/?term=\&h=1 Lest 2.7.2020.

9. Bakken IJ, Ariansen AMS, Knudsen GP et al. The Norwegian Patient Registry and the Norwegian Registry for Primary Health Care: Research potential of two nationwide health-care registries. Scand J Public Health 2020; 48: 49-55. [PubMed][CrossRef]

10. Størdal K, Bakken IJ, Greve-Isdahl M et al. Sars-CoV-2 hos barn og ungdom i Norge: påvist smitte, sykehusinnleggelser og underliggende tilstander. Tidsskr Nor Legeforen 2020;140. doi: 10.4045/tidsskr.20.0457. [PubMed][CrossRef]

11. Nystad W, Hjellvik V, Larsen IK et al. Underliggende tilstander hos voksne med covid-19. Tidsskr Nor Legeforen 2020; 140. doi: 10.4045/tidsskr.20.0512. [PubMed][CrossRef]

12. Folkehelseinstituttet. Meldingssystem for smittsomme sykdommer(MSIS). https://www.fhi.no/hn/helseregistre-og-registre/msis/ Lest 2.7.2020.

13. Personregisteret (PREG). https://www.nhn.no/grunndata/personregisteret-preg/ Lest 2.7.2020.

14. Juvet LK, Laake I, Vestrheim DF. Covid-19: Letalitet og infeksjonsletalitet for alvorlig Covid-19, 1.oppdatering - en hurtigoversikt. Oslo: Folkehelseinstituttet, 2020.

https://www.fhi.no/publ/2020/covid-19-letalitet-og-infeksjonsletalitet-for-alvorlig-covid-19-1.oppdater/ Lest 9.11.2020.

15. Gudbjartsson DF, Helgason A, Jonsson H et al. Spread of SARS-CoV-2 in the Icelandic population. $\mathrm{N}$ Engl J Med 2020; 382: 2302-15. [PubMed][CrossRef]

16. Folkehelseinstituttet. COVID-19 Ukerapport - uke 23. https://www.fhi.no/contentassets/8a971e7boa3c4ao6bdbf381ab52e6157/vedlegg/andre-halvar2020/2020.11.18-ukerapport-uke-46-covid-19.pdf Lest 9.11.2020. 
17. Helsedirektoratet. Koronavirus - beslutninger og anbefalinger.

https://www.helsedirektoratet.no/veiledere/koronavirus Lest 9.11.2020.

18. McMichael TM, Currie DW, Clark S et al. Epidemiology of Covid-19 in a long-term care facility in King County, Washington. N Engl J Med 2020;382: 2005-11. [PubMed][CrossRef]

19. Kittang BR, Hofacker SV, Solheim SP et al. Utbrudd av covid-19 ved tre sykehjem i Bergen. Tidsskr Nor Legeforen 2020; 140. doi:10.4045/tidsskr.20.0405. [PubMed][CrossRef]

20. Onder G, Rezza G, Brusaferro S. Case-fatality rate and characteristics of patients dying in relation to COVID-19 in Italy. JAMA 2020; 323: 1775-6. [PubMed][CrossRef]

21. Folkehelseinstituttet. Foreløpige tall for covid-19-assosierte dødsfall i Dødsårsaksregisteret. https://www.fhi.no/hn/helseregistre-og-registre/dodsarsaksregisteret/forelopige-tall-for-covid-19assosierte-dodsfall-i-dodsarsaksregisteret/ Lest 9.11.2020.

Publisert: 3. desember 2020. Tidsskr Nor Legeforen. DOI:10.4045/tidsskr.20.0693

Mottatt 1.9.2020, første revisjon innsendt 21.10.2020, godkjent 9.11.2020.

Publisert under åpen tilgang CC BY-ND. Lastet ned fra tidsskriftet.no 26. april 2023 